\title{
The Development of Character Education in Primary Schools Through the Enhancement of School Culture
}

\author{
F.Samong, A. Suryadi, D. Budimansyah \\ General Education, Graduate Studies \\ Universitas Pendidikan Indonesia \\ Bandung, Indonesia \\ f.samong@upi.edu
}

\begin{abstract}
The purpose of this study is to determine whether school culture develops character education in elementary school. This is a quantitative investigation and the instrument named "School Culture" was used for this study. The variables of the school culture are school's vision and mission, school's tradition, principal's role, professional collaboration, relation in school, collegiality, students' involvement, and parents' and society's cooperation. The inventories were applied to 22 elementary schools of Yayasan Salib Suci in West Java, Indonesia. The statistical findings indicated that school culture has influence to develop the character education. The most significant influence is the relation among the members of the school community. The key to the success of the improvement of the quality of the school is how each member of the school interacts with each other. A positive pattern of relationship and communication will have a significant role in developing the school, students' character education, and increasing students' achievement.
\end{abstract}

Keywords: character education, community, relation, school culture

\section{INTRODUCTION}

Schools, just like other institutions, own their own culture which influences the conduct of the whole school community members in the process of working and learning. Even though each school applies the same rules and regulations issued by the department of education or by the institution they belong to, they have their own characteristics in their school culture. This is the culture that is lived up by each school member.

The key to success of a school is, among other, the enthusiasm to work and learn among the students, teacher, and other school staff within the school. The strong culture of a school is not only cultivated within seconds, but through an extended time [1]. School culture is a system which is embraced by the whole school members which distinguishes one school from another. The term culture contains school values, traditions, language, unwritten rules, rituals, and symbols. [2]. The comprehension of school culture cannot be separated from the origin of the formation of school values developed through daily activities at school. School culture constructs the behavior of school community members through everyday life at school.

Basically, every school has its own culture, i.e. The commands of moral, ritual, and various forms of interrelationship among individuals within the school. As something which is internalized into each individual, the culture does not only play a role in the formal aspects of school. It also plays a role in the informal aspects which influences the minds, feelings, and everyday conduct of individuals belonging to the school. School culture encapsulates all daily activities performed by the members of the school community.

Schools should assist their students to get to know, to comprehend, to internalize, and to strive to implement the values in everyday life. School community members should become models for one another and are responsible to administer the character education. [3]. School is a place where values are preserved and becomes social environment for the students to learn. The life values that exist in the community will later be learned at school. School culture which becomes the atmosphere of school's everyday life helps the school to implement character education [4].

School environment can form the personality and character of the students. School is not only a place where students can imitate those who become the role model and example, but it is also a place where students study and where the members form good characters as well. Therefore, the system of values which are formed and constructed by the school members are basically closely related to the development and the nurture of the character of the students. When the values are lived up and integrated by the whole school members, a positive culture of the school will be achieved. If the values are lived up just by one student, it cannot be called a culture. However, if the values are lived up by the whole school members, become a habit of the whole school members, and influence other students, it will become a culture which constructs and develops a good school culture.

Therefore, school can become a moral community which supports the growth of an individual and its members so they are able to discover their significance and to be conscious of their profession. The moral responsibility of an educator in the context of child education is to help them to achieve success and to reach achievements, so they are endowed with academic excellence which enables them to live independently and to be a whole individual who possesses integrity. To promote moral community in the context of the development of learning motivation is the characteristics of an educational institution [5]. 
A good school culture which serves as the spirit of each community member will support the advancement of the school and especially the improvement in the quality of character education. Therefore, the research about school culture and character education is urgently required to enforce the academic foundation of the development of school culture and character education

\section{THE PURPOSE OF THE RESEARCH}

The goal of the study is to analyze the influence of school culture toward character education in elementary school. This study will be based on the following questions: (i) Does school culture influence the character education in elementary schools? (ii) How does school culture influence the character education in elementary schools?

\section{RESEARCH METHOD}

This is a quantitative research by using survey instruments called School Culture that involves some variables such as vision and mission, schools' tradition, principal's role, professional collaboration, relation in school, collegiality, students' involvement, and partnership between the parents, society, and school.

The research was conducted during the 2014-2015 academic year. Data were collected from 22 elementary schools of Yayasan Salib Suci in West Java, Indonesia. The sample was selected by using random sampling design of elementary school students. This research instrument was applied to 550 students in 22 schools.

The instrument was developed by the researcher based on the books "The Shaping School Culture" and "The Shaping School Culture Field book” by Kent D. Peterson \& Terrence E. Deal.

The researcher decided to visit all the 22 primary schools which became the part of the research. The students who were chosen to fill in the questionnaire are the sixth graders. The population of grade 6 is 1086 students. After an intensive discussion with the principals of the schools, the researcher decided that 550 students were chosen to fill in the questionnaire which were distributed to the 22 schools. The researcher then handed out the questionnaire and explained to the students about it, and as soon as the students completed filling them in, he directly collected the questionnaire.

\section{RESULTS}

School culture has a significant role in the development of the quality of character education in schools. The indicators of school culture in this research are the vision and mission of the schools, schools' traditions, the role of the principals, professional collaboration, the relations at school, school's collegiality, the involvement of students, and the cooperation with the parents and the community. The achieved score under the variable of school culture is above the median (5.5) with an average score of 8.79 . Of all the eight sub-variable of school culture, the variable of relation at school has the highest score with 9.13. This shows that the relation among the principal, teachers, students, and school staff is relatively high. There are some indicators which fall below the average score of school culture. They are: the collegiality at school, the cooperation between parents and community, and school tradition. The indicator, which is considered the lowest compared to the other aspects is a school tradition with the score of 8.27. The result indicates that school culture has a significant influence on character education. As a variable of school culture, relation in school is the most significant influenced by instructional leadership.

\section{DISCUSSION}

The result shows that school culture in an important element in developing a school unit and the academic achievement. The history of the school itself affects the school's culture. On the other hand, school culture also affects the pattern of relation and communication among the member of the school. Relation at school in the variable of school culture has the highest significance, which is 9.13. The pattern of relationships and communication can affect the development of the school in the future. For example: if the relation in school cannot be performed well, it will interrupt the daily activities and operations at the school. If the relationships and communication between the principal and the teachers do not go well, it will effect on the implementation of the teaching - learning process both in school and in class as well. The key to success to improve the quality of the school is on how the school members interact among each other, especially among the teachers, and between the teachers and the principal [6]. A positive pattern of relationships and communication plays a significant role in the development of the school [7].

Additionally, a good communication pattern among the teachers gives positive effects on the development of students' academic performance and achievements in schools [8]. Social interaction in school as well as in the classroom also plays a role in developing the school culture. The school culture itself can affect every individual involved in a school unit [9]. The teachers in school should develop many aspects: a good relation and communication pattern of interaction with the students, pedagogy, learning process, expertise and conduct of a teacher, and students' academic achievement [10]. Furthermore, a teacher is the agent of change in school. The empowerment of teachers is an important step to create an effective learning community. Teachers are obliged to master three professional dimensions of a teacher:

a) Implementing the principals of education and teaching

b) Knowing each student personally

c) Collaborating both principles above into an effective decision making [10]

The dimensions above help teachers to become a leader who has an important role in developing and evaluating school culture. Each school member, including the teachers, has the opportunity to develop school culture. Teachers have a significant role to develop and form the school culture [11].

School culture is closely connected to the pattern of relationship among the members. Originally, the school was not considered as an educational institution or foundation which could develop the relationship among the members. School was a relation which bound its members. This bond, which created a commitment among the members served as the foundation to interrelate among 
each other. Talks, discussions, and outings became the foundation to cultivate and develop the bond.

Every school member realizes that he or she is a member of a school community. This awareness is important and becomes the bond for them as members of a school community. School is a community in which its members are bound to honor and respect each other, to share ideology and the richness of their experience. Fellowship and diversity become an important aspect of building a school community. (Sergiovanni, 1994, pp. xvxvi) [10].

The fellowship in a school community is established through a relation pattern and a good communication among its members. The good pattern of relation and communication among the staff and workers as well as the students in a school plays an important role to achieve the objectives of the school. The principal, as the leader in a school, plays a significant role in this matter. He should comprehend the culture of the school, both in the past and at the present, and in the future as well in order that the school can achieve the objectives effectively. The culture of the school in the past determines the passion and spirit of each school member. The comprehension of the school's history in the past is the key to understand the present school's culture. A principal also has to comprehend the school's culture which exists presently. The existing school culture in the form of values, principles, ceremonies, and rituals are the factors which determine the conduct and thoughts of every school member. The comprehension about the existing school culture will help the principal to determine the objectives of the school in the future. School culture will help the principal to manage the school unit to achieve the dream they seek to reach [2].

Teachers, as the members of a school community, after comprehending and liven up the school's culture, are motivated to be responsible and to integrate the values in their conduct both in school and in class. A teacher who has transformed and shows good characters is expected to be an agent of change who can help encourage his or her students to build good characters too. Teachers become role models who can cultivate values not only through the teaching of character education in class, but also through a good conduct in everyday life. This implies that the teacher, he should have already been able to show a good character. The good values can be integrated into every subject in order that the students as the members of a school can acquire the same comprehension and experience of good character.

School environment can shape the personality and character of the students. It is not only a place where the students can emulate those who become the role models and examples, but also a place where the students study and, additionally, a place to form a good character as well. Therefore, the system of values which is formed and established by the member of the school are basically closely connected to the development and the nurture of the students' character. When the values are lived up and integrated simultaneously, they will become a positive culture of the school. However, if they are only implemented by one student, they cannot be called a culture. The values which are lived up and can influence other students will become a culture which develops and builds a good school culture.
To sum up, school can become a moral community which supports the growth of its individuals and members in order for them to discover their meaning in living up their professions. The moral responsibility of an educator in the context of child education is to help the children to become successful and to reach achievements, so they will have academically excellent which enables them to live independently and to become a whole human who has integrity. Developing moral community in the context of developing the motivation to study is the characteristic of an educational institution [5].

\section{ACKNOWLEDGMENT}

This research was supported by The Order of the Holy Cross Sang Kristus Indonesia Province. The authors are thankful to Salib Suci Foundation, Salib Suci Primary Schools for providing the necessary facilities and great assistance for the research. We would also like to show our gratitude to the reviewers for their so-called insights.

\section{REFERENCES}

[1] Deal, T., Peterson, K., (2009). Shaping School Culture Pitfalls, Paradoxes, \& Promises. Second Edition. (2009). San Francisco, CA: Jossey-Bass.

[2] Peterson, K. \& Deal, T. (2009). The Shaping School Culture Fieldbook. Second Edition. San Francisco, CA: Jossey-Bass.

[3] Lickona, T., Schaps, E., \& Lewis, C. (1997). Eleven Principles of Effective Character Education. Social Studies Review, 37 (1), pp. 29-31

[4] Wren, D.J., (1999). School Culture:Exploring the Hidden Curriculum. 34(135), pp. 593-596

[5] Koesoema, A.D., (2012). Pendidikan Karakter Utuh dan Menyeluruh. Yogyakarta : Kanisius.

[6] Barth, R.S., (1990). Improving Schools from Within - Teachers, Parents, and Principals Can Make the Difference. San Fransisco, CA : Jossey-Bass.K. Elissa, "Title of paper if known," unpublished.

[7] Sergiovanni, T.J., (1994). Building Community in Schools. San Francisco, CA: Jossey-Bass.

[8] Sergiovanni, T.J., (2000). The Lifeworld of Leadership: Creating Culture, Community, and Personal Meaning in Our Schools. San Francisco, CA: Jossey-Bass

[9] Adamy, P. \& Heinecke, W. (2005). The Influence of Organizational Culture on Technology Integration in Teacher Education. Journal of Technology and Teacher Education, 13(2), 233-235.J. Clerk Maxwell, A Treatise on Electricity and Magnetism, 3rd ed., vol. 2. Oxford: Clarendon, 1892, pp.68-73.

[10] Sergiovanni, T.J., (1994). Building Community in Schools. San Francisco, CA: Jossey-Bass

[11] Roby, D.E., (2011). Teacher Leaders Impacting School Culture. Education. 131 (4). pp. 782-790

[12] Beachum, F. \& Dentith, A.M. (2004). Teacher Leaders Creating Cultures of School Renewal and Transformation. Educational Forum, 68(3), pp. 276-286.

[13] Benninga, J. S. (Ed.) (1991). Moral, Character and Civic Education in the Elementary School. New York: Teachers College Pres.

[14] Hadden, P. D. (2000). When The School is The Community: A Case Study of Fourche Valley School, Briggsville, Arkansas Washington DC.: Office of Educational Research and Improvement, pp.113-137.

[15] Negis-Isik, A., Gursel, M. (2013). Organizational Culture in a Successful Primary School: An Ethnographic Case Study. Educational Sciences: Theory \& Practice, 13(1), pp. 221-228. 